THE SURROGACY (REGULATION) BILL, 2016

\title{
ARRANGEMENT OF CLAUSES
}

\section{CHAPTER I}

PRELIMINARY

\section{Clauses}

1. Short title, extent and commencement.

2. Definitions.

\section{CHAPTER II}

REGULATION OF SURROGACY CLINICS

3. Prohibition and regulation of surrogacy clinics.

\section{CHAPTER III}

REGULATION OF SURROGACY AND SURROGACY PROCEDURES

4. Regulation of surrogacy and surrogacy procedures.

5. Prohibition of conducting surrogacy.

6. Written informed consent of surrogate mother.

7. Prohibition to abandon child born through surrogacy.

8. Number of oocytes or embryos to be implanted.

9. Prohibition of abortion

\section{CHAPTER IV}

REGISTRATION OF SURROGACY CLINICS

10. Registration of surrogacy clinics.

11. Certificate of registration.

12. Cancellation or suspension of registration.

13. Appeal.

\section{CHAPTER V}

National Surrogacy Board

14. Constitution of National Surrogacy Board.

15. Term of office of Members.

16. Meetings of Board.

17. Vacancies, etc., not to invalidate proceedings of Board.

18. Disqualifications for appointment as Member.

19. Temporary association of persons with Board for particular purposes.

20. Authentication of orders and other instruments of Board.

21. Eligibility of Member for re-appointment.

22. Functions of Board. 
Clauses

23. Constitution of State Surrogacy Board.

24. Composition of State Board.

25. Term of office of Members.

26. Meetings of State Board.

27. Vacancies, etc., not to invalidate proceedings of State Board.

28. Disqualifications for appointment as Member.

29. Temporary association of persons with State Board for particular purposes.

30. Authentication of orders and other instruments of State Board.

31. Eligibility of Member for re-appointment.

\section{CHAPTER VI}

APPROPRIATE AUTHORITY

32. Appointment of appropriate authority.

33. Functions of appropriate authority.

34. Powers of appropriate authority.

\section{CHAPTER VII}

OFFENCES AND PENALITIES

35. Prohibition of commercial surrogacy, exploitation of surrogate mothers and children born through surrogacy.

36. Punishment for contravention of provisions of Act.

37. Punishment for initiation of commercial surrogacy.

38. Penalty for contravention of provisions of Act or rules for which no specific punishment is provided.

39. Presumption in case of surrogacy.

40. Offence to be cognizable, non-bailable and non-compoundable.

41. Cognizance of offences.

42. Certain provisions of the Code of Criminal Procedure, 1973 not to apply.

\section{CHAPTER VIII}

Miscellaneous

43. Maintenance of records.

44. Power to search and seize records, etc.

45. Protection of action taken in good faith.

46. Application of other laws not barred.

47. Power to make rules.

48. Power to make regulations.

49. Rules and regulations to be laid before Parliament.

50. Transitional provision.

51. Power to remove difficulties. 


\section{THE SURROGACY (REGULATION) BILL, 2016}

A

BILL

to constitute National Surrogacy Board, State Surrogacy Boards and appointment of appropriate authorities for regulation of the practice and process of surrogacy and for matters connected therewith or incidental thereto.

BE it enacted by Parliament in the Sixty-seventh Year of the Republic of India as follows:-

\section{CHAPTER I}

PRELIMINARY

1. (1) This Act may be called the Surrogacy (Regulation) Act, 2016.

(2) It extends to the whole of India except the State of Jammu and Kashmir.

Short title, extent and

(3) It shall come into force on such date as the Central Government may, by notification in the Official Gazette, appoint.

2. In this Act, unless the context otherwise requires,-

Definitions.

(a) "abandoned child" means a child-

(i) born out of surrogacy procedure;

(ii) deserted by his intending parents or guardians; and

(iii) who has been declared as abandoned by the appropriate authority after due enquiry; 
(b) "altruistic surrogacy" means the surrogacy in which no charges, expenses, fees, remuneration or monetary incentive of whatever nature, except the medical expenses incurred on surrogate mother and the insurance coverage for the surrogate mother, are given to the surrogate mother or her dependents or her representative;

(c) "appropriate authority" means the appropriate authority appointed under 5 section 32 ;

(d) "Board" means the National Surrogacy Board constituted under section 14;

(e) "clinical establishment" shall have the same meaning as assigned to it in the Clinical Establishments (Registration and Regulation) Act, 2010;

(f) "commercial surrogacy" means commercialisation of surrogacy services or procedures or its component services or component procedures including selling or buying of human embryo or trading in the sale or purchase of human embryo or gametes or selling or buying or trading the services of surrogate motherhood by way of giving payment, reward, benefit, fees, remuneration or monetary incentive in cash or kind, to the surrogate mother or her dependents or her representative, except the medical expenses incurred on the surrogate mother and the insurance coverage for the surrogate mother;

$(g)$ "couple" means the legally married Indian man and woman above the age of 21 years and 18 years respectively;

(h) "egg" includes the female gamete;

(i) "embryo" means a developing or developed organism after fertilisation till the end of fifty-six days;

(j) "fertilisation" means the penetration of the ovum by the spermatozoan and fusion of genetic materials resulting in the development of a zygote;

(k) "foetus" means a human organism during the period of its development 25 beginning on the fifty-seventh day following fertilisation or creation (excluding any time in which its development has been suspended) and ending at the birth;

(l) "gamete" means sperm and oocyte;

(m) "gynaecologist" shall have the same meaning as assigned to it in the Pre-conception and Pre-natal Diagnostic Techniques (Prohibition of Sex Selection) Act, 1994;

(n) "human embryologist" means a person who possesses any post-graduate medical qualification in the field of human embryology recognised under the Indian Medical Council Act, 1956 or who possesses a post-graduate degree in human embryology from a recognised university with not less than two years of clinical 102 of 1956. experience;

(o) "implantation" means the attachment and subsequent penetration by the zona-free blastocyst, which starts five to seven days following fertilisation;

$(p)$ "infertility" means the inability to conceive after five years of unprotected coitus or other proven medical condition preventing a couple from conception;

(q) "insurance" means an arrangement by which a company, individual or intending couple undertake to provide a guarantee of compensation for specified loss, damage, illness or death of surrogate mother during the process of surrogacy;

$(r)$ "intending couple" means a couple who have been medically certified to be an infertile couple and who intend to become parents through surrogacy; 
$(s)$ "Member" means a Member of the National Surrogacy Board or a State Surrogacy Board, as the case may be;

$(t)$ "notification" means a notification published in the Official Gazette;

(u) "oocyte" means naturally ovulating oocyte in the female genetic tract;

(v) "Paediatrician" means a person who possess a post-graduate qualification in paediatrics as recognised under the Indian Medical Council Act, 1956;

(w) "prescribed" means prescribed by rules made under this Act;

$(x)$ "registered medical practitioner" means a medical practitioner who possesses any recognised medical qualification as defined in clause $(h)$ of section 2 of the Indian Medical Council Act, 1956 and whose name has been entered in a State Medical Register;

(y) "regulation" means regulations made by the Board under this Act;

(z) "State Board" means the State Surrogacy Board constituted under section 23;

(za) "State Government" in relation to Union territory with Legislature, means the Administrator of the Union territory appointed by the President under article 239 of the Constitution;

$(z b)$ "surrogacy" means a practice whereby one woman bears and gives birth to a child for an intending couple with the intention of handing over such child to the intending couple after the birth;

$(z c)$ "surrogacy clinic" means surrogacy clinic or centre or laboratory, conducting assisted reproductive technology services, invitro fertilisation services, genetic counselling centre, genetic laboratory, Assisted Reproductive Technology Banks conducting surrogacy procedure or any clinical establishment, by whatsoever name called conducting surrogacy procedures in any form;

$(z d)$ "surrogacy procedures" means all gynaecological or obstetrical or medical procedures, techniques, tests, practices or services involving handling of human gametes and human embryo in surrogacy;

(ze) "surrogate mother" means a woman bearing a child who is genectically related to the intending couple, through surrogacy from the implantation of embryo in her womb and fulfils the conditions as provided in sub-clause $(b)$ of clause (iii) of section 4;

$(z f)$ "zygote" means the fertilised oocyte prior to the first cell division.

\section{CHAPTER II}

\section{REGULATION OF SURROGACY CLINICS}

3. On and from the date of commencement of this Act,-

(i) no surrogacy clinic, unless registered under this Act, shall conduct or associate with, or help in any manner, in conducting activities relating to surrogacy and surrogacy procedures;

(ii) no surrogacy clinic, paediatrician, gynaecologist, human embryologist, registered medical practitioner or any person shall conduct, offer, undertake, promote or associate with or avail of commercial surrogacy in any form;

(iii) no surrogacy clinic shall employ or cause to be employed or take services of any person, whether on honorary basis or on payment who does not possess such qualifications as may be prescribed;

(iv) no registered medical practitioner, gynaecologist, paediatrician, human

Prohibition and regulation of surrogacy clinics. 
embryologist or any other person shall conduct or cause to be conducted or aid in conducting by himself or through any other person surrogacy or surrogacy procedures at a place other than a place registered under this Act;

$(v)$ no surrogacy clinic, registered medical practitioner, gynaecologist, paediatrician, human embryologist or any other person shall promote, publish, canvass, 5 propagate or advertise or cause to be promoted, published, canvassed, propagated or advertised whichmother;

(a) is aimed at inducing or is likely to induce a woman to act as a surrogate

(b) is aimed at promoting a surrogacy clinic for commercial surrogacy or 10 promoting commercial surrogacy in general;

(c) seeks or aimed at seeking a woman to act as a surrogate mother;

(d) states or implies that a woman is willing to become a surrogate mother;

or

(e) advertises commercial surrogacy in print or electronic media or in any 15 other form;

(vi) no surrogacy clinic, registered medical practitioner, gynaecologist, paediatrician, human embryologist, intending couple or any other person shall conduct or cause abortion during the period of surrogacy without the written consent of the surrogate mother and on authorisation of the same by the appropriate authority concerned:

Provided that the authorisation of the appropriate authority shall be subject to, and in compliance with, the provisions of the Medical Termination of Pregnancy Act, 1971;

(vii) no surrogacy clinic, registered medical practitioner, gynaecologist, 25 paediatrician, human embryologist, intending couple or any other person shall store a human embryo or gamete for the purpose of surrogacy:

Provided that nothing contained in this clause shall affect such storage for other legal purposes like sperm banks, IVF and medical research for such period and in such manner as may be prescribed.

Regulation of surrogacy and surrogacy procedures.

\section{CHAPTER III}

\section{REGULATION OF SURROGACY AND SURROGACY PROCEDURES}

4. On and from the date of commencement of this Act,-

(i) no place including a surrogacy clinic shall be used or caused to be used by any person for conducting surrogacy or surrogacy procedures, except for the purposes specified in clause (ii) and after satisfying all the conditions specified in clause (iii);

(ii) no surrogacy or surrogacy procedures shall be conducted, undertaken, performed or availed of, except for the following purposes, namely:-

(a) when either or both members of the couple is suffering from proven infertility;

(b) when it is only for altruistic surrogacy purposes;

(c) when it is not for commercial purposes or for commercialisation of surrogacy or surrogacy procedures;

(d) when it is not for producing children for sale, prostitution or any other form of exploitation; and

(e) any other condition or disease as may be specified by regulations made by the Board; 
(iii) no surrogacy or surrogacy procedures shall be conducted, undertaken, performed or initiated, unless the Director or in-charge of the surrogacy clinic and the person qualified to do so are satisfied, for reasons to be recorded in writing, that the following conditions have been fulfilled, namely:-

(a) the intending couple is in possession of a certificate of essentiality issued by the appropriate authority, after satisfying for itself, for the reasons to be recorded in writing, about the fulfilment of the following conditions, namely:-

(I) a certificate of proven infertility in favour of either or both members of the intending couple from a District Medical Board.

Explanation.-For the purposes of this item, the expression "District Medical Board" means a medical board under the Chairpersonship of Chief Medical Officer or Chief Civil Surgeon or Joint Director of Health Services of the district and comprising of at least two other specialists, namely, the chief gynaecologist or obstetrician and chief paediatrician of the district;

(II) an order concerning the parentage and custody of the child to be born through surrogacy, have been passed by a court of the Magistrate of the first class or above, on an application made by the intending couple and surrogate mother;

(III) an insurance coverage of such amount as may be prescribed in favour of the surrogate mother from an insurance company or an agent recognised by the Insurance Regulatory and Development Authority established under the Insurance Regulatory and Development Authority Act, 1999;

(b) the surrogate mother is in possession of an eligibility certificate issued by the appropriate authority on fulfilment of the following conditions, namely:-

(I) no woman, other than an ever married woman having a child of her own and between the age of 25 to 35 years on the day of implantation, shall be a surrogate mother or help in surrogacy by donating her egg or oocyte or otherwise;

(II) no person, other than a close relative of the intending couple, shall act as a surrogate mother and be permitted to undergo surrogacy procedures as per the provisions of this Act;

(III) no women shall act as a surrogate mother or help in surrogacy in any way, by providing gametes or by carrying the pregnancy, more than once in her lifetime:

Provided that the number of attempts for surrogacy procedures on the surrogate mother shall be such as may be prescribed;

(IV) a certificate of medical and psychological fitness for surrogacy and surrogacy procedures from a registered medical practitioner;

(c) an eligibility certificate for intending couple is issued separately by the appropriate authority on fulfilment of the following conditions, namely:-

( $I$ ) the age of the intending couple is between 23 to 50 years in case of female and between 26 to 55 years in case of male on the day of certification;

(II) the intending couple are married for at least five years and are Indian citizens;

(III) the intending couple have not had any surviving child biologically or through adoption or through surrogacy earlier:

Provided that nothing contained in this item shall affect the intending couple who have a child and who is mentally or physically challenged or suffers from life threatening disorder or fatal illness with no permanent 
cure and approved by the appropriate authority with due medical certificate from a District Medical Board;

(IV) such other conditions as may be specified by the regulations.

Prohibition of conducting surrogacy.

Written informed consent of surrogate mother.

Prohibition to abandon child born through surrogacy.

\section{Number of} oocytes or embryos to be implanted.

Prohibition of abortion.

5. No person including a relative or husband of a surrogate mother or intending couple shall seek or encourage to conduct any surrogacy or surrogacy procedures on her except for the purpose specified in clause (ii) of section 4 .

6. No person shall seek or conduct surrogacy procedures unless he has-

(i) explained all known side effects and after effects of such procedures to the surrogate mother concerned;

(ii) obtained in the prescribed form, the written informed consent of the surrogate 10 mother to undergo such procedures in the language she understands.

7. The intending couple shall not abandon the child, born out of a surrogacy procedure, whether within India or outside, for any reason whatsoever, including but not restricted to, any genetic defect, birth defect, any other medical condition, the defects developing subsequently, sex of the child or conception of more than one baby and the like:

Provided that any child born out of surrogacy procedure, shall be deemed to be a biological child of the intending couple and the said child shall be entitled to all the rights and privileges available to a natural child under any law for the time being in force.

8. The number of oocytes or embryos to be implanted in the surrogate mother for the purpose of surrogacy, shall be such as may be prescribed.

9. No person, organisation, surrogacy clinic, laboratory or clinical establishment of any kind shall force the surrogate mother to abort at any stage of surrogacy except in such conditions as may be prescribed.

\section{CHAPTER IV}

REGISTRATION OF SURROGACY CLINICS

10. (1) No person shall establish any surrogacy clinic for undertaking surrogacy or to clinics. render surrogacy procedures in any form unless such clinic is duly registered under this Act.

(2) Every application for registration under sub-section (1) shall be made to the appropriate authority in such form, manner and shall be accompanied by such fees as may be prescribed.

(3) Every surrogacy clinic which is conducting surrogacy or surrogacy procedures, partly or exclusively, referred to in clause (ii) of section 4 shall, within a period of sixty days from the date of appointment of appropriate authority, apply for registration:

Provided that such clinic shall cease to conduct any such counselling or procedures 35 on the expiry of six months from the date of commencement of this Act, unless such clinic has applied for registration and is so registered separately or till such application is disposed of, whichever is earlier.

(4) No surrogacy clinic shall be registered under this Act, unless the appropriate authority is satisfied that such clinic is in a position to provide such facilities and maintain 40 such equipment and standards including specialised manpower, physical infrastructure and diagnostic facilities as may be prescribed.

11. (1) The appropriate authority shall after holding an enquiry and after satisfying itself that the applicant has complied with all the requirements of this Act, rules and regulations made thereunder, grant a certificate of registration to the surrogacy clinic, 45 
within a period of ninety days from the date of application received by it, in such form, on payment of such fees and in such manner, as may be prescribed.

(2) Where, after the enquiry and after giving an opportunity of being heard to the applicant, the appropriate authority is satisfied that the applicant has not complied with the 5 requirements of this Act or the rules or regulations made thereunder, it shall, for reasons to be recorded in writing, reject the application for registration.

(3) Every certificate of registration shall be valid for a period of three years and shall be renewed in such manner and on payment of such fees as may be prescribed.

(4) The certificate of registration shall be displayed by the surrogacy clinic at a conspicuous place.

12. (1) The appropriate authority may, suo motu, or on receipt of a complaint, issue a notice to the surrogacy clinic to show cause as to why its registration should not be suspended or cancelled for the reasons mentioned in the notice.

(2) If after giving a reasonable opportunity of being heard to the surrogacy clinic, the appropriate authority is satisfied that there has been a breach of the provision of the Act or the rules or regulations made thereunder, it may, without prejudice to any criminal action that it may take against such clinic, suspend its registration for such period as it may think fit or cancel its registration, as the case may be.

(3) Notwithstanding anything contained in sub-sections (1) and (2), if the appropriate 20 authority is of the opinion that it is necessary or expedient to do so in the public interest, it may, for reasons to be recorded in writing, suspend the registration of any surrogacy clinic without issuing any notice under sub-section (1).

13. The surrogacy clinic may, within a period of thirty days from the date of receipt of the communication relating to order of rejection of application, suspension or cancellation

25 of registration passed by the appropriate authority under section 12, prefer an appeal against such order to-

(a) the State Government, where the appeal is against the order of the appropriate authority of a State;

(b) to the Central Government, where the appeal is against the order of the appropriate authority of a Union territory,

in such manner as may be prescribed.

\section{CHAPTER V}

\section{NATIONAL SURROGACy BoARD}

14. (1) The Central Government shall, by notification, constitute a Board to be known as the National Surrogacy Board to exercise the powers and perform the functions conferred on the Board under this Act.

(2) The Board shall consist of-

(a) the Minister in-charge of the Ministry of Health and Family Welfare, the Chairperson, ex officio;

(b) the Secretary to the Government of India in-charge of the Department dealing with the surrogacy matter, Vice-Chairperson, ex officio;

(c) three women Members of Parliament, of whom two shall be elected by the House of the People and one by the Council of States, Members, ex officio;

(d) three Members of the Ministries of the Central Government in-charge of Women and Child Development, Legislative Department in the Ministry of Law and Justice and the Ministry of Home Affairs not below the rank of Joint Secretary, Members, ex officio;

Cancellation or suspension of registration. 
(e) the Director-General of Health Services of the Central Government, Member, ex officio;

(f) ten expert Members to be appointed by the Central Government in such manner as may be prescribed and two each from amongst-

(i) eminent medical geneticists or human embryologists;

(ii) eminent gynaecologists and obstetricians or experts of stri-roga or prasuti-tantra;

(iii) eminent social scientists;

(iv) representatives of women welfare organisations; and

(v) representatives from civil society working on women's health and 10 child issues,

possessing of such qualifications and experience as may be prescribed;

( $g$ ) four Chairpersons of the State Boards to be nominated by the Central Government by rotation to represent the States and the Union territories, two in the alphabetical order and two in the reverse alphabetical order, Member, ex officio;

(h) an officer, not below the rank of a Joint Secretary to the Central Government, in-charge of Surrogacy Division in the Ministry of Health and Family Welfare, who shall be the Member-Secretary, ex officio.

Term of office of Members.

Meetings of Board.
15. (1) The term of office of a Member, other than an ex officio Member, shall beyears:

(a) in case of nomination under clause (c) of sub-section (2) of section 14, three 20

Provided that the term of such Member shall come to an end as soon as the Member becomes a Minister or Minister of State or Deputy Minister, or the Speaker or the Deputy Speaker of the House of the People, or the Deputy Chairman of the Council of States or ceases to be a Member of the House from which she was elected; and

(b) in case of appointment under clause (f) of sub-section (2) of section 14, one year:

Provided that the person to be appointed as Member under this clause shall be of such age as may be prescribed.

(2) Any vacancy occurring in the office whether by reason of his death, resignation or inability to discharge his functions owing to illness or other incapacity, shall be filled by the Central Government by making a fresh appointment within a period of one month from the date on which such vacancy occurs and the Member so appointed shall hold office for the remainder of the term of office of the person in whose place he is so appointed.

(3) The Vice-Chairperson shall perform such functions as may be assigned to him by the Chairperson from time to time.

16. (1) The Board shall meet at such places and times and shall observe such rules of procedure in regard to the transaction of business at its meetings (including the quorum at its meetings) as may be determined by the regulations:

Provided that the Board shall meet at least once in six months.

(2) The Chairperson shall preside at the meeting of the Board and if for any reason the Chairperson is unable to attend the meeting of the Board, the Vice-Chairperson shall preside at the meetings of the Board.

(3) All questions which come up before any meeting of the Board shall be decided by 45 a majority of the votes of the Members present and voting, and in the event of an equality 
of votes, the Chairperson, or in his absence, the Vice-Chairperson shall have and exercise a second or casting vote.

(4) The Members, other than ex officio Members, shall receive only compensatory travelling expenses for attending the meeting of the Board.

17. No act or proceeding of the Board shall be invalid merely by reason of-

(a) any vacancy in, or any defect in the constitution of, the Board; or Board; or

(b) any defect in the appointment of a person acting as a Member of the

(c) any irregularity in the procedure of the Board not affecting the merits of the case.

18. (1) A person shall be disqualified for being appointed and continued as a Member if, he-

(a) has been adjudged as an insolvent; or

(b) has been convicted of an offence, which in the opinion of the Central Government, involves moral turpitude; or

(c) has become physically or mentally incapable of acting as a Member; or

(d) has acquired such financial or other interest, as is likely to affect prejudicially his functions as a Member; or

(e) has so abused his position, as to render his continuance in office prejudicial to the public interest; or

$(f)$ is a practicing member or an office bearer of any association representing surrogacy clinics, having financial or other interest likely to affect prejudicially, his function as a Member; or

$(g)$ is an office bearer, heading or representing, any of the professional bodies having commercial interest in surrogacy or infertility.

(2) The Members referred to in clause $(f)$ of section 14 shall not be removed from his office except by an order of the Central Government on the ground of his proved misbehaviour or incapacity after the Central Government, has, on an inquiry, held in accordance with the procedure prescribed in this behalf by the Central Government, come to the conclusion that the Member ought on any such ground to be removed.

(3) The Central Government may suspend any Member in respect of whom an inquiry under sub-section (2) is being initiated or pending until the Central Government has passed an order on receipt of the report of the inquiry.

19. (1) The Board may associate with itself, in such manner and for such purposes as may be determined by the regulations, any person whose assistance or advice it may desire in carrying out any of the provisions of this Act.

(2) A person associated with the Board under sub-section (1) shall have a right to take part in the discussions relevant to that purpose, but shall not have a right to vote at a meeting of the Board and shall not be a Member for any other purpose.

20. All orders and decisions of the Board shall be authenticated by the signature of the Chairperson and all other instruments issued by the Board shall be authenticated by the signature of the Member-Secretary of the Board.

21. Subject to the other terms and conditions of service as may be prescribed, any person ceasing to be a Member shall be eligible for re-appointment as such Member:

Vacancies, etc., not to invalidate proceedings of Board.

Disqualifications for appointment as Member.

Temporary association of persons with Board for particular purposes.

Authentication of orders and other instruments of Board.

Eligibility of Member for reappointment. 
Functions of Board.

Constitution of State Surrogacy Board.

Composition of State Board.
Provided that no Member other than an ex officio Member shall be appointed for more than two consecutive terms.

22. The Board shall discharge the following functions, namely:-

(a) to advise the Central Government on policy matters relating to surrogacy;

(b) to review and monitor the implementation of the Act, rules and regulations 5 made thereunder and recommend to the Central Government, changes therein;

(c) to lay down code of conduct to be observed by persons working at surrogacy clinics; to set the minimum standards of physical infrastructure, laboratory and diagnostic equipment and expert manpower to be employed by the surrogacy clinics;

(d) to oversee the performance of various bodies constituted under the Act and 10 take appropriate steps to ensure their effective performance;

(e) to supervise the functioning of State Surrogacy Boards; and

$(f)$ such other functions as may be prescribed.

23. Each State and Union territory having Legislature shall constitute a Board to be known as the State Surrogacy Board or the Union territory Surrogacy Board, as the case 15 may be, which shall discharge the following functions, namely:-

(i) to review the activities of the appropriate authorities functioning in the State or Union territory and recommend appropriate action against them;

(ii) to monitor the implementation of the provisions of the Act, rules and regulations made thereunder and make suitable recommendations relating thereto, to 20 the Board;

(iii) to send such consolidated reports as may be prescribed in respect of the various activities undertaken in the State under the Act to the Board and the Central Government; and

(iv) such other functions as may be prescribed.

24. The State Board shall consist of-

(a) the Minister in-charge of Health and Family Welfare in the State, Chairperson, ex officio;

(b) the Secretary in-charge of the Department of Health and Family Welfare, Vice-Chairperson, ex officio;

(c) Secretaries or Commissioners in-charge of the Departments of Women and Child Development, Social Welfare, Law and Justice and Home Affairs or their nominees, Members, ex officio;

(d) the Director-General of Health and Family Welfare of the State Government, Member, ex officio;

(e) three women Members of the State Legislative Assembly or Union territory Legislative Council, Members, ex officio;

(f) ten expert Members to be appointed by the State Government in such manner as may be prescribed, two each from amongst-

(i) eminent medical geneticists or human embryologists;

(ii) eminent gynaecologists and obstetricians or experts of stri-roga or prasuti-tantra;

(iii) eminent social scientists;

(iv) representatives of women welfare organisations; and 
(v) representatives from civil society working on women's health and child issues,

possessing of such qualifications and experiences as may be prescribed;

$(g)$ an officer not below the rank of Joint Secretary to the State Government in-charge of Family Welfare, who shall be the Member-Secretary, ex officio.

25. (1) The term of office of a Member, other than an ex officio Member, shall be-

$(a)$ in case of nomination under clause $(e)$ of section 24 , three years:

Provided that the term of such Member shall come to an end as soon as the Member becomes a Minister or Minister of State or Deputy Minister, or the Speaker or the Deputy Speaker of the Legislative Assembly, or the Deputy Chairman of the Legislative Council or ceases to be a Member of the House from which she was elected; and

(b) in case of appointment under clause $(f)$ of section 24 , one year:

Provided that the person to be appointed as Member under this clause shall be of such age, as may be prescribed.

(2) Any vacancy occurring in the office whether by reason of his death, resignation or inability to discharge his functions owing to illness or other incapacity, shall be filled within a period of one month from the date on which such vacancy occurs by the State Government by making a fresh appointment and the Member so appointed shall hold office for the remainder of the term of office of the person in whose place he is so appointed.

(3) The Vice-Chairperson shall perform such functions as may be assigned to him by the Chairperson from time to time.

26. (1) The State Board shall meet at such places and times and shall observe such rules of procedure in regard to the transaction of business at its meetings (including the quorum at its meetings) as may be determined by the regulations:

Provided that the State Board shall meet at least once in four months.

(2) The Chairperson shall preside at the meeting of the Board and if for any reason the Chairman is unable to attend the meeting of the State Board, the Vice-Chairperson shall preside at the meetings of the State Board.

(3) All questions which come up before any meeting of the State Board shall be decided by a majority of the votes of the members present and voting, and in the event of an equality of votes, the Chairperson, or in his absence, the Vice-Chairperson shall have and exercise a second or casting vote.

(4) The Members, other than, ex officio Members, shall receive only compensatory travelling expenses for attending the meetings of the State Board.

27. No act or proceeding of the State Board shall be invalid merely by reason of-

(a) any vacancy in, or any defect in the constitution of, the State Board; or Board; or

(b) any defect in the appointment of a person acting as a Member of the State

(c) any irregularity in the procedure of the State Board not affecting the merits of the case. if, he-

28. (1) A person shall be disqualified for being appointed and continued as a Member

(a) has been adjudged as an insolvent; or

Vacancies, etc., not to invalidate proceedings of State Board.

(b) has been convicted of an offence, which in the opinion of the State Government, involves moral turpitude; or 
(c) has become physically or mentally incapable of acting as a member; or

(d) has acquired such financial or other interest, as is likely to affect prejudicially his functions as a Member; or

(e) has so abused his position, as to render his continuance in office prejudicial to the public interest; or

$(f)$ is a practicing Member or an office bearer of any association representing surrogacy clinics, having financial or other interest likely to affect prejudicially, his function as a Member; or

$(g)$ is an office bearer, heading or representing, any of the professional bodies having commercial interest in surrogacy or infertility.

(2) The Members referred to in clause $(f)$ of section 24 shall not be removed from his office except by an order of the State Government on the ground of his proved misbehaviour or incapacity after the State Government, has, on an inquiry, held in accordance with the procedure prescribed in this behalf by the State Government, come to the conclusion that the Member ought on any such ground to be removed.

Temporary association of persons with State Board for particular purposes.

Authentication of orders and other instruments of State Board.

Eligibility of Member for reappointment.

Appointment of appropriate authority.

(3) The State Government may suspend any Member in respect of whom an inquiry under sub-section (2) is being initiated or pending until the State Government has passed an order on receipt of the report of the inquiry.

29. (1) The State Board may associate with itself, in such manner and for such purposes as may be determined by the regulations, any person whose assistance or advice it may 20 desire in carrying out any of the provisions of this Act.

(2) A person associated with it by the State Board under sub-section (1) shall have a right to take part in the discussions relevant to that purpose, but shall not have a right to vote at a meeting of the State Board and shall not be a Member for any other purpose.

30. All orders and decisions of the State Board shall be authenticated by the signature 25 of the Chairperson and all other instruments issued by the State Board shall be authenticated by the signature of the Member-Secretary of the State Board.

31. Subject to the other terms and conditions of service as may be prescribed, any person ceasing to be a Member shall be eligible for re-appointment as such Member:

Provided that no Member other than an ex officio Member shall be appointed for more 30 than two consecutive terms.

\section{CHAPTER VI}

\section{APPROPRIATE AUTHORITY}

32. (1) The Central Government shall, within a period of ninety days from the date of commencement of this Act, by notification, appoint one or more appropriate authorities for 35 each of the Union territories for the purposes of this Act.

(2) The State Government shall, within a period of ninety days from the date of commencement of this Act, by notification, appoint one or more appropriate authorities for the whole or part of the State for the purposes of this Act.

(3) The appropriate authority, under sub-section (1) or sub-section (2), shall, -

(a) when appointed for the whole of the State or the Union territory, consist of-

(i) an officer of or above the rank of the Joint Director of Health and Family Welfare Department-Chairperson;

(ii) an eminent woman representing women's organisation-Member; 
(iii) an officer of Law Department of the State or the Union territory concerned not below the rank of a Deputy Secretary-Member; and

(iv) an eminent registered medical practitioner-Member:

Provided that any vacancy occurring therein shall be filled within one month of the

(b) when appointed for any part of the State or the Union territory, be officers of such other rank as the State Government or the Central Government, as the case may be, may deem fit.

33. The appropriate authority shall discharge the following functions, namely:-

(a) to grant, suspend or cancel registration of a surrogacy clinic;

Functions of appropriate

(b) to enforce the standards to be fulfilled by the surrogacy clinics;

(c) to investigate complaints of breach of the provisions of this Act, rules and regulations made thereunder and take legal action as per provision of this Act;

(d) to take appropriate legal action against the use of surrogacy by any person at any place other than prescribed, suo motu or brought to its notice, and also to initiate independent investigations in such matter;

(e) to supervise the implementation of the provisions of this Act, rules and regulations made thereunder;

(f) to recommend to the Board and State Boards about the modifications required in the rules and regulations in accordance with changes in technology or social conditions;

( $g$ ) to take action after investigation of complaints received by it against the surrogacy clinics; and

(h) to consider and grant or reject any application under clause (vi) of section 3 and sub-clauses $(a)$ to $(c)$ of clause (iii) of section 4 .

34. (1) The appropriate authority shall exercise the powers in respect of the following matters, namely:-

(a) summoning of any person who is in possession of any information relating

Powers of appropriate authority. to violation of the provisions of this Act, rules and regulations made thereunder;

(b) production of any document or material object relating to clause $(a)$;

(c) search any place suspected to be violating the provisions of this Act, rules and regulations made thereunder; and

(d) such other powers as may be prescribed.

(2) The appropriate authority shall maintain the details of registration of surrogacy clinics, cancellation of registration, renewal of registration, grant of certificates to the intending couple and surrogate mothers or any other matter pertaining to grant of licence, etc., of the surrogacy clinics in such format as may be prescribed.

\section{CHAPTER VII}

\section{OFFENCES AND PENALTIES}

35. (1) No person, organisation, surrogacy clinic, laboratory or clinical establishment of any kind shall-

(a) undertake commercial surrogacy, provide commercial surrogacy or its related component procedures or services in any form or run a racket or an organised group to empanel or select surrogate mothers or use individual brokers or intermediaries to arrange for surrogate mothers and for surrogacy procedures, at such clinics, laboratories or at any other place;

Prohibition of commercial surrogacy, exploitation of surrogate mothers and children born through surrogacy. 
(b) issue, publish, distribute, communicate or cause to be issued, published, distributed or communicated any advertisement in any manner regarding commercial surrogacy by any means whatsoever, scientific or otherwise;

(c) abandon or disown or exploit or cause to be abandoned, exploited or disowned in any form the child or children born through surrogacy;

(d) exploit or cause to be exploited the surrogate mother or the child born through surrogacy in any manner whatsoever;

(e) sell human embryo or gametes for the purpose of surrogacy and run an agency, a racket or an organisation for selling, purchasing or trading in human embryos or gametes for the purpose of surrogacy;

$(f)$ import or shall help in getting imported in whatsoever manner, the human embryo or human gametes for surrogacy or for surrogacy procedures.

(2) Notwithstanding anything contained in the Indian Penal Code, contraventions of the provisions of clauses $(a)$ to $(f)$ of sub-section $(l)$ by any person shall be an offence punishable with imprisonment for a term which shall not be less than ten years and with fine which may extend to ten lakh rupees.

(3) For the purposes of this section, the expression "advertisement" includes any notice, circular, label, wrapper or any other document including advertisement through internet or any other media, in electronic or print form and also includes any visible representation made by means of any hoarding, wall-painting, signal light, sound, smoke or gas.

Punishment for contravention of provisions of Act.

Punishment for initiation of commercial surrogacy.

Penalty for contravention of provisions of Act or rules for which no specific punishment is provided.

Presumption in case of surrogacy.
36. (1) Any registered medical practitioner, gynaecologists, paediatrician, human embryologists or any person who owns a surrogacy clinic or employed with such a clinic or centre or laboratory and renders his professional or technical services to or at such clinic or centre or laboratory, whether on an honorary basis or otherwise, and who contravenes any of the provisions of this Act (other than the provisions referred to in section 35), rules and regulations made thereunder shall be punishable with imprisonment for a term which shall not be less than five years and with fine which may extend to ten lakh rupees.

(2) In case of subsequent or continuation of the offence referred to in sub-section (1), the name of the registered medical practitioner shall be reported by the appropriate authority to the State Medical Council concerned for taking necessary action including suspension of registration for a period of five years.

37. Any intending couple or any person who seeks the aid of any surrogacy clinic, laboratory or of a registered medical practitioner, gynaecologist, paediatrician, human embryologist or any other person for commercial surrogacy or for conducting surrogacy procedures for commercial purposes shall be punishable with imprisonment for a term which shall not be less than five years and with fine which may extend to five lakh rupees for the first offence and for any subsequent offence with imprisonment which may extend to ten years and with fine which may extend to ten lakh rupees.

38. Whoever contravenes any of the provisions of this Act, rules or regulations made thereunder for which no penalty has been elsewhere provided in this Act, shall be punishable with imprisonment for a term which shall not be less than three years and with fine which may extend to five lakh rupees and in the case of continuing contravention with an additional fine which may extend to ten thousand rupees for every day during which such contravention continues after conviction for the first such contravention.

39. Notwithstanding anything contained in the Indian Evidence Act, 1872, the court shall presume, unless the contrary is proved, that the woman or surrogate mother was compelled by her husband, the intending couple or any other relative, as the case may be, to render surrogacy services, procedures or to donate gametes for the purpose other than those specified in clause (ii) of section 4 and such person shall be liable for abetment of such offence under section 37 and shall be punishable for the offence specified under that section. 
40. Notwithstanding anything contained in the Code of Criminal Procedure, 1973, every offence under this Act shall be cognizable, non-bailable and non-compoundable.

41. (1) No court shall take cognizance of any offence punishable under this Act except on a complaint in writing made by-

(a) the appropriate authority concerned, or any officer or an agency authorised in this behalf by the Central Government or the State Government, as the case may be, or the appropriate authority; or

(b) a person including a social organisation who has given notice of not less than fifteen days in the manner prescribed, to the appropriate authority, of the alleged offence and of his intention to make a complaint to the court.

(2) No court inferior to that of a Metropolitan Magistrate or a Judicial Magistrate of the first class shall try any offence punishable under this Act.

42. Notwithstanding anything contained in the Code of Criminal Procedure, 1973, Chapter XXIA of the said Code relating to plea of bargaining shall not apply to the offences under this Act.

\section{CHAPTER VIII}

\section{Miscellaneous}

43. (1) The surrogacy clinic shall maintain all records, charts, forms, reports, consent letters, agreements and all the documents under this Act and they shall be preserved for a period of twenty-five years or such period as may be prescribed:

Provided that, if any criminal or other proceedings are instituted against any surrogacy clinic, the records and all other documents of such clinic shall be preserved till the final disposal of such proceedings.

(2) All such records shall, at all reasonable times, be made available for inspection to the appropriate authority or to any other person authorised by the appropriate authority in this behalf.

44. (1) If the appropriate authority has reason to believe that an offence under this Act has been or is being committed at any surrogacy clinic or any other place, such authority or any officer authorised in this behalf may, subject to such rules as may be prescribed, enter and search at all reasonable times with such assistance, if any, as such authority or officers considers necessary, such surrogacy clinic or any other place and examine any record, register, document, book, pamphlet, advertisement or any other material object found therein and seize and seal the same if such authority or officer has reason to believe that it may furnish evidence of the commission of an offence punishable under this Act.

2 of 1974. $35 \quad$ (2) The provisions of the Code of Criminal Procedure, 1973 relating to search and seizure shall apply, as far as may be, to all action taken by the appropriate authority or any officer authorised by it under this Act.

45. No suit, prosecution or other legal proceeding shall lie against the Central Government or the State Government or the appropriate authority or any officer authorised by the Central Government or the State Government or by the appropriate authority for anything which is in good faith done or intended to be done in pursuance of the provision of this Act.

46. The provisions of this Act shall be in addition to, and not in derogation of, the provisions of any other law for the time being in force.
Offence to be cognizable, non-bailable and noncompoundable.

Cognizance of offences.

Certain provisions of the Code of Criminal Procedure, 1973 not to apply.

Maintenance of records.

Power to search and seize records, etc.

Protection of action taken in good faith.

Application of other laws not barred. 

make rules.

47. (1) The Central Government may, by notification and subject to the condition of pre-publication, make rules for carrying out the provisions of this Act.

(2) In particular, and without prejudice to the generality of the foregoing power, such rules may provide for-

(a) the minimum qualifications for persons employed at a registered surrogacy 5 clinic under clause (iii) of section 3;

(b) the manner in which a person shall store human embryo or gamete under clause (vii) of section 3;

(c) the insurance coverage in favour of the surrogate mother from an insurance company under item (iii) of sub-clause (a) of clause (iii) of section 4;

(d) the number of attempts of surrogacy or providing of gametes under the proviso to item (iii) of sub-clause (b) of clause (iii) of section 4;

(e) the form in which consent of a surrogate mother has to be obtained under clause (ii) of section 6 ;

(f) the number of oocytes or embryos to be implanted in the surrogate mother 15 under section 8 ;

$(g)$ the conditions under which the surrogate mother may be allowed for abortion during the process of surrogacy under section 9;

(h) the form and manner in which an application shall be made for registration and the fee payable thereof under sub-section (2) of section 10;

(i) the facilities to be provided, equipment and other standards to be maintained by the surrogacy clinics under sub-section (4) of section 10;

(j) the period, manner and form in which a certificate of registration shall be issued under sub-section ( 1 ) of section 11;

(k) the manner in which the certificate of registration shall be renewed and the 25 fee payable for such renewal under sub-section (3) of section 11;

(l) the manner in which an appeal may be preferred under section 13;

$(m)$ the qualifications and experiences to the Members as admissible under clause $(f)$ of sub-section (2) of section 14;

$(n)$ the procedures for conducting an inquiry against the Members under 30 sub-section (2) of section 18;

(o) the conditions under which a Member of the Board eligible for re-appointment under section 21;

$(p)$ the other functions of the Board under clause $(e)$ of section 22;

(q) the manner in which reports shall be furnished by the State and Union 35 territory Boards to the Board and the Central Government under clause (iii) of section 23;

(r) the other functions of the State Board under clause (iv) of section 23;

$(s)$ the qualifications and experiences to the Members as admissible under clause $(f)$ of section 24 ;

$(t)$ the age of the person to be appointed as a Member, referred to in clause $(f)$ of section 24 , under the proviso to clause $(b)$ of sub-section $(1)$ of section 25 ; 
(u) the procedures for conducting an inquiry against the members under sub-section (2) of section 28;

(v) the conditions under which the members of the State Board eligible for re-appointment under section 31 ;

$(w)$ empowering the appropriate authority in any other matter under clause $(d)$ of section 33 ;

$(x)$ the other powers of appropriate authority under clause $(d)$ of sub-section $(1)$ of section 34;

(y) the particulars of the details of registration of surrogacy clinics, cancellation of registration, etc., in such format under sub-section (2) of section 34;

$(z)$ the manner of giving notice by a person under clause $(b)$ of sub-section $(1)$ of section 41 ;

$(z a)$ the period up to which records, charts, etc., shall be preserved under sub-section (1) of section 43;

$(z b)$ the manner in which the seizure of documents, records, objects, etc., shall be made and the manner in which seizure list shall be prepared and delivered under sub-section (1) of section 44; and

$(z c)$ any other matter which is to be, or may be, or in respect of which provision is to be made by rules.

48. The Board may, with the prior approval of the Central Government, by notification, make regulations not inconsistent with the provisions of this Act and the rules made thereunder to provide for-

(a) the fulfilment of any other condition under which eligibility certificate to be issued by the appropriate authority under Item (IV) of sub-clause (c) of clause (iii) of section 4;

(b) the time and place of the meetings of the Board and the procedure to be followed for the transaction of business at such meetings and the number of Members which shall form the quorum under sub-section (1) of section 16;

(c) the manner in which a person may be temporarily associated with the Board under sub-section $(1)$ of section 19 ;

(d) the time and place of the meetings of the State Board and the procedure to be followed for the transaction of business at such meetings and the number of Members which shall form the quorum under sub-section (1) of section 26;

(e) the manner in which a person may be temporarily associated with the Board under sub-section $(1)$ of section 29 ;

$(f)$ any other matter which is required to be, or may be, specified by regulations.

49. Every rules and every regulations made under this Act shall be laid, as soon as may be after it is made, before each House of Parliament, while it is in session, for a total period of thirty days which may be comprised in one session or in two or more successive sessions, and if, before the expiry of the session immediately following the session or the

Rules and regulations to be laid before Parliament. successive sessions aforesaid, both Houses agree in making any modification in the rule or regulation or both Houses agree that the rule or regulation should not be made, the rule or regulation shall thereafter have effect only in such modified form or be of no effect, as the case may be; so, however, that any such modification or annulment shall be without prejudice to the validity of anything previously done under that rule or regulation or notification.

50. Subject to the provisions of this Act, there shall be provided a gestation period of Transitional ten months from the date of coming into force of this Act to existing surrogate mothers' to provision. protect their well being. 
Power to remove difficulties.
51. (1) If any difficulty arises in giving effect to the provisions of this Act, the Central Government may, by order published in the Official Gazette make such provisions not inconsistent with the provisions of the said Act as appear to it to be necessary or expedient for removing the difficulty:

Provided that no order shall be made under this section after the expiry of a period of 5 two years from the date of commencement of this Act.

(2) Every order made under this section shall be laid, as soon as may be after it is made, before each House of Parliament. 


\section{STATEMENT OF OBJECTS AND REASONS}

India has emerged as a surrogacy hub for couples from different countries for past few years. There have been reported incidents of unethical practices, exploitation of surrogate mothers, abandonment of children born out of surrogacy and import of human embryos and gametes. Widespread condemnation of commercial surrogacy in India has been regularly reflected in different print and electronic media for last few years. The Law Commission of India has, in its 228th Report, also recommended for prohibition of commercial surrogacy by enacting a suitable legislation. Due to lack of legislation to regulate surrogacy, the practice of surrogacy has been misused by the surrogacy clinics, which leads to rampant of commercial surrogacy and unethical practices in the said area of surrogacy.

2. In the light of above, it had become necessary to enact a legislation to regulate surrogacy services in the country, to prohibit the potential exploitation of surrogate mothers and to protect the rights of children born through surrogacy.

3. The Surrogacy (Regulation) Bill, 2016, inter alia, provides for the following, namely:-

(a) to constitute the Surrogacy Boards at National and State level;

(b) to allow ethical altruistic surrogacy to the intending infertile Indian married couple between the age of 23-50 years and 26-55 years for female and male respectively;

(c) the intending couples should be legally married for at least five years and should be Indian citizens to undertake surrogacy or surrogacy procedures;

(d) to provide that the intending couples shall not abandon the child, born out of a surrogacy procedure, under any condition and the child born out of surrogacy procedure shall have the same rights and privileges as are available to the biological child;

(e) the surrogate mother should be a close relative of the intending couple and should be an ever married woman having a child of her own and between the age of 25-35 years;

(f) to provide that the surrogate mother shall be allowed to act as surrogate mother only once;

$(g)$ to constitute the Surrogacy Board at National level which shall exercise and perform functions conferred on it under the Act. It is also proposed to constitute Surrogacy Boards at the State and Union territory level to perform similar functions in respective States and Union territories;

(h) to appoint one or more appropriate authorities at State and Union territory level which shall be the executive bodies for implementing the provisions of the Act;

(i) to provide that the surrogacy clinics shall be registered only after the appropriate authority is satisfied that such clinics are in a position to provide facilities and can maintain equipments and standards including specialised manpower, physical infrastructure and diagnostic facilities as may be provided in the rules and regulations;

(j) to provide that no person, organisation, surrogacy clinic, laboratory or clinical establishment of any kind shall undertake commercial surrogacy, issue advertisements regarding commercial surrogacy, abandon the child born through surrogacy, exploit the surrogate mother, sell human embryo or import human embryo for the purpose of surrogacy and contravention of the said provisions shall be an offence punishable with imprisonment for a term which shall not be less than ten years and with fine which may extend to ten lakh rupees. 
4. The Notes on Clauses explain in detail the various provisions contained in the Surrogacy (Regulation) Bill, 2016.

5. The Bill seeks to achieve the above objectives.

NEw DeLHI;

JAGAT PRAKASH NADDA

The 28th October, 2016. 


\section{Notes on clauses}

Clause 1.-This clause relates to Short title, Extent and Commencement of the proposed legislation.

Clause 2.- This clause contains the definitions of various expressions used in the proposed legislation.

Clause 3.- This clause relates to prohibition and regulation of surrogacy clinics.

Sub-clause $(i)$ of this clause provides that no surrogacy clinic, unless registered under this Act, shall conduct or associate with, or help in any manner, in conducting activities relating to surrogacy and surrogacy procedures.

Sub-clause $(\mathrm{ii})$ of this clause provides that no surrogacy clinic, paediatrician, gynaecologist, human embryologist, registered medical practitioner or any person shall conduct, offer, undertake, promote or associate with or avail of commercial surrogacy in any form.

Sub-clause (iii) of this clause provides that no surrogacy clinic shall employ or cause to be employed or take services of any person, whether on honorary basis or on payment who does not possess such qualifications as may be prescribed.

Sub-clause (iv) of this clause provides that no registered medical practitioner, gynecologist, pediatrician, human embryologist or any other person shall conduct or cause to be conducted or aid in conducting by himself or through any other person surrogacy or surrogacy procedures at a place other than a place registered under this Act.

Sub-clause $(v)$ of this clause provides that no surrogacy clinic, registered medical practitioner, gynecologist, pediatrician, human embryologist or any other person shall promote, publish, canvass, propagate or advertise or cause to be promoted, published, canvassed, propagated or advertised which-

(a) is aimed at inducing or is likely to induce a woman to act as a surrogate mother;

(b) is aimed at promoting a surrogacy clinic for commercial surrogacy or promoting commercial surrogacy in general;

(c) seeks or aimed at seeking a woman to act as a surrogate mother;

(d) states or implies that a woman is willing to become a surrogate mother; or

(e) advertises commercial surrogacy in print or electronic media or in any other form.

Sub-clause (vi) of this clause provides that no surrogacy clinic, registered medical practitioner, gynecologist, pediatrician, human embryologist, intending couple or any other person shall conduct or cause abortion during the period of surrogacy without the written consent of the surrogate mother and on authorisation of the same by the appropriate authority concerned. However, that the authorisation of the appropriate authority shall be subject to, and in compliance with, the provisions of the Medical Termination of Pregnancy Act, 1971.

Sub-clause (vii) of this clause provides that no surrogacy clinic, registered medical practitioner, gynecologist, pediatrician, human embryologist, intending couple or any other person shall store a human embryo or gamete for the purpose of surrogacy. However, that nothing contained in this sub-clause shall affect such storage for other legal purposes like sperm banks, IVF and medical research for such period and in such manner as may be prescribed.

Clause 4.-This clause relates to regulation of surrogacy and surrogacy procedures. 
Sub-clause $(i)$ of this clause provides that no place including a surrogacy clinic shall be used or caused to be used by any person for conducting surrogacy or surrogacy procedures, except for the purposes specified in sub-clause (ii) and after satisfying all the conditions specified in sub-clause (iii).

Sub-clause (ii) of this clause provides that no surrogacy or surrogacy procedures shall be conducted, undertaken, performed or availed of, except for the following purposes, namely:- (a) when either or both members of the couple is suffering from proven infertility; (b) when it is only for altruistic surrogacy purposes; $(c)$ when it is not for commercial purposes or for commercialisation of surrogacy or surrogacy procedures; $(d)$ when it is not for producing children for sale, prostitution or any other form of exploitation; and $(e)$ any other condition or disease as may be specified by regulations made by the Board.

Sub-clause (iii) of this clause provides that no surrogacy or surrogacy procedures shall be conducted, undertaken, performed or initiated, unless the Director or in-charge of the surrogacy clinic and the person qualified to do so are satisfied, for reasons to be recorded in writing, that the following conditions have been fulfilled, namely:-

(a) the intending couple is in possession of a certificate of essentiality issued by the appropriate authority, after satisfying for itself, for the reasons to be recorded in writing, about the fulfilment of the following conditions, namely:-

(I) a certificate of proven infertility in favour of either or both members of the intending couple from a District Medical Board;

(II) an order concerning the parentage and custody of the child to be born through surrogacy, have been passed by a court of the Magistrate of the first class or above, on an application made by the intending couple and surrogate mother;

(III) an insurance coverage of such amount as may be prescribed in favour of the surrogate mother from an insurance company or an agent recognised by the Insurance Regulatory and Development Authority established under the Insurance Regulatory and Development Authority Act, 1999;

(b) the surrogate mother is in possession of an eligibility certificate issued by the appropriate authority on fulfilment of the following conditions, namely:-

(I) no woman, other than an ever married woman having a child of her own and between the age of 25 to 35 years on the day of implantation, shall be a surrogate mother or help in surrogacy by donating her egg or oocyte or otherwise;

(II) no person, other than a close relative of the intending couple, shall act as a surrogate mother and be permitted to undergo surrogacy procedures as per the provisions of this Act;

(III) no women shall act as a surrogate mother or help in surrogacy in any way, by providing gametes or by carrying the pregnancy, more than once in her lifetime. However, that the number of attempts for surrogacy procedures on the surrogate mother shall be such as may be prescribed;

(IV) a certificate of medical and psychological fitness for surrogacy and surrogacy procedures from a registered medical practitioner;

(c) an eligibility certificate for intending couple is issued separately by the appropriate authority on fulfilment of the following conditions, namely:-

( $I$ ) the age of the intending couple is between 23 to 50 years in case of female and between 26 to 55 years in case of male on the day of certification;

(II) the intending couple are married for at least five years and are Indian citizens; 
(III) the intending couple have not had any surviving child biologically or through adoption or through surrogacy earlier. However, that nothing contained in this item shall affect the intending couple who have a child and who is mentally or physically challenged or suffers from life threatening disorder or fatal illness with no permanent cure and approved by the appropriate authority with due medical certificate from a District Medical Board; and

(IV) such other conditions as may be specified by the regulations.

Clause 5.-This clause relates to prohibition of conducting surrogacy.

This clause provides that no person including a relative or husband of a surrogate mother or intending couple shall seek or encourage to conduct any surrogacy or surrogacy procedures on her except for the purpose specified in sub-clause (ii) of clause 4.

Clause 6.-This clause relates to written informed consent of surrogate mother.

This clause provides that no person shall seek or conduct surrogacy procedures unless he has - (i) explained all known side effects and after effects of such procedures to the surrogate mother concerned; (ii) obtained in the prescribed form, the written informed consent of the surrogate mother to undergo such procedures in the language she understands.

Clause 7.-This clause relates to prohibition to abandon child born through surrogacy.

This clause provides that the intending couple shall not abandon the child, born out of a surrogacy procedure, whether within India or outside, for any reason whatsoever, including but not restricted to, any genetic defect, birth defect, any other medical condition, the defects developing subsequently, sex of the child or conception of more than one baby and the like. However, that any child born out of surrogacy procedure, shall be deemed to be a biological child of the intending couple and the said child shall be entitled to all the rights and privileges available to a natural child under any law for time being in force.

Clause 8.-This clause relates to number of oocytes or embryos to be implanted.

This clause provides that the number of oocytes or embryos to be implanted in the surrogate mother for the purpose of surrogacy, shall be such as may be prescribed.

Clause 9.-This clause relates to prohibition of abortion.

This clause provides that no person, organisation, surrogacy clinic, laboratory or clinical establishment of any kind shall force the surrogate mother to abort at any stage of surrogacy except in such conditions as may be prescribed.

Clause 10.-This clause relates to registration of surrogacy clinics.

Sub-clause (1) of this clause provides that no person shall establish any surrogacy clinic for undertaking surrogacy or to render surrogacy procedures in any form unless such clinic is duly registered under this Act.

Sub-clause (2) of this clause provides that every application for registration under sub-clause (1) shall be made to the appropriate authority in such form, manner and shall be accompanied by such fees as may be prescribed.

Sub-clause (3) of this clause provides that every surrogacy clinic which is conducting surrogacy or surrogacy procedures, partly or exclusively, referred to in sub-clause (ii) of clause 4 shall, within a period of sixty days from the date of appointment of appropriate authority, apply for registration. However, that such clinic shall cease to conduct any such counseling or procedures on the expiry of six months from the date of commencement of this Act, unless such clinic has applied for registration and is so registered separately or till such application is disposed of, whichever is earlier.

Sub-clause (4) of this clause provides that no surrogacy clinic shall be registered under this Act, unless the appropriate authority is satisfied that such clinic is in a position to 
provide such facilities and maintain such equipment and standards including specialised manpower, physical infrastructure and diagnostic facilities as may be prescribed.

Clause 11.-This clause relates to certificate of registration.

Sub-clause (1) of this clause provides that the appropriate authority shall after holding an enquiry and after satisfying itself that the applicant has complied with all the requirements of this Act, rules and regulations made thereunder, grant a certificate of registration to the surrogacy clinic, within a period of ninety days from the date of application received by it, in such form, on payment of such fees and in such manner, as may be prescribed.

Sub-clause (2) of this clause provides that where, after the inquiry and after giving an opportunity of being heard to the applicant, the appropriate authority is satisfied that the applicant has not complied with the requirements of this Act or the rules or regulations made thereunder, it shall, for reasons to be recorded in writing, reject the application for registration.

Sub-clause (3) of this clause provides that every certificate of registration shall be valid for a period of three years and shall be renewed in such manner and on payment of such fees as may be prescribed.

Sub-clause (4) of this clause provides that the certificate of registration shall be displayed by the surrogacy clinic at a conspicuous place.

Clause 12.- This clause relates to cancellation or suspension of registration.

Sub-clause (1) of this clause provides that the appropriate authority may, suo motu or on receipt of a complaint, issue a notice to the surrogacy clinic to show cause as to why its registration should not be suspended or cancelled for the reasons mentioned in the notice.

Sub-clause (2) of this clause provides that if after giving a reasonable opportunity of being heard to the surrogacy clinic, the appropriate authority is satisfied that there has been a breach of the provision of the Act or the rules or regulations made thereunder, it may, without prejudice to any criminal action that it may take against such clinic, suspend its registration for such period as it may think fit or cancel its registration, as the case may be.

Sub-clause (3) of this clause provides that notwithstanding anything contained in the sub-clauses (1) and (2) of clause 12, if the appropriate authority is of the opinion that it is necessary or expedient to do so in the public interest, it may, for reasons to be recorded in writing, suspend the registration of any surrogacy clinic without issuing any notice under sub-section (1) of clause 12.

Clause 13.-This clause relates to appeal.

This clause provides that the surrogacy clinic may, within a period of thirty days from the date of receipt of the communication relating to order of rejection of application, suspension or cancellation of registration passed by the appropriate authority under clause 12, prefer an appeal against such order to- $(a)$ the State Government, where the appeal is against the order of the appropriate authority of a State; $(b)$ to the Central Government, where the appeal is against the order of the appropriate authority of a Union territory, in such manner as may be prescribed.

Clause 14.-This clause relates to constitution of National Surrogacy Board.

Sub-clause (1) of this clause provides that the Central Government shall, by notification, constitute a Board to be known as the National Surrogacy Board to exercise the powers and perform the functions conferred on the Board under this Act.

Sub-clause (2) of this clause provides that the Board shall consist of - $(a)$ the Minister in-charge of the Ministry of Health and Family Welfare, the Chairperson, ex officio; $(b)$ the Secretary to the Government of India in- charge of the Department dealing with the surrogacy matter, Vice-Chairperson, ex officio; (c) three women Members of Parliament, of whom two shall be elected by the House of the People and one by the Council of States, Members, 
ex officio; $(d)$ three Members of the Ministries of Central Government in charge of Women and Child Development, Legislative Department in the Ministry of Law and Justice and the Ministry of Home Affairs not below the rank of Joint Secretary, Members, ex officio; $(e)$ the Director General of Health Services of the Central Government, Member, ex officio; $(f)$ ten expert Members to be appointed by the Central Government in such manner as may be prescribed and two each from amongst-(i) eminent medical geneticists or human embryologists; (ii) eminent gynaecologists and obstetricians or experts of stri-roga or prasuti-tantra; (iii) eminent social scientists; (iv) representatives of women welfare organisations; and $(v)$ representatives from civil society working on womens' health and child issues, possessing of such qualifications and experience as may be prescribed; ( $g$ ) four Chairpersons of the State Boards to be nominated by the Central Government by rotation to represent the States and the Union territories, two in the alphabetical order and two in the reverse alphabetical order, Member, ex officio; $(h)$ an officer, not below the rank of a Joint Secretary to the Central Government, in charge of Surrogacy Division in the Ministry of Health and Family Welfare, who shall be the Member-Secretary, ex officio.

Clause 15.-This clause relates to term of office of Members.

Sub-clause (1) of this clause provides that the term of office of a Member, other than an ex officio Member, shall be- $(a)$ in case of nomination of three women Members of Parliament, three years. However, that the term of such Member shall come to an end as soon as the Member becomes a Minister or Minister of State or Deputy Minister, or the Speaker or the Deputy Speaker of the House of the People, or the Deputy Chairman of the Council of States or ceases to be a Member of the House from which she was elected; $(b)$ in case of appointment of ten expert Members, one year. However, that the person to be appointed as Member under this clause shall be of such age as may be prescribed.

Sub-clause (2) of this clause provides that any vacancy occurring in the office whether by reason of his death, resignation or inability to discharge his functions owing to illness or other incapacity, shall be filled by the Central Government by making a fresh appointment within a period of one month from the date on which such vacancy occurs and the Member so appointed shall hold office for the remainder of the term of office of the person in whose place he is so appointed.

Sub-clause (3) of this clause provides that the Vice-Chairperson shall perform such functions as may be assigned to him by the Chairperson from time to time.

Clause 16.- This clause relates to meetings of Board.

Sub-clause (1) of this clause provides that the Board shall meet at such places and times and shall observe such rules of procedure in regard to the transaction of business at its meetings (including the quorum at its meetings) as may be determined by the regulations. However, that the Board shall meet at least once in six months.

Sub-clause (2) of this clause provides that the Chairperson shall preside at the meeting of the Board and if for any reason the Chairperson is unable to attend the meeting of the Board, the Vice-Chairperson shall preside at the meetings of the Board.

Sub-clause (3) of this clause provides that all questions which come up before any meeting of the Board shall be decided by a majority of the votes of the Members present and voting, and in the event of an equality of votes, the Chairperson, or in his absence, the Vice-Chairperson shall have and exercise a second or casting vote.

Sub-clause (4) of this clause provides that the Members, other than ex officio Members, shall receive only compensatory travelling expenses for attending the meeting of the Board.

Clause 17.- This clause relates to vacancies, etc., not to invalidate proceedings of Board.

This clause provides that no act or proceeding of the Board shall be invalid merely by reason of - $(a)$ any vacancy in, or any defect in the constitution of the Board; or $(b)$ any 
defect in the appointment of a person acting as a Member of the Board; or (c) any irregularity in the procedure of the Board not affecting the merits of the case.

Clause 18.- This clause relates to disqualifications for appointment as Member.

Sub-clause (1) of this clause provides that a person shall be disqualified for being appointed and continued as a Member if, he- $(a)$ has been adjudged as an insolvent; or (b) has been convicted of an offence, which in the opinion of the Central Government, involves moral turpitude; or $(c)$ has become physically or mentally incapable of acting as a Member; or $(d)$ has acquired such financial or other interest, as is likely to affect prejudicially his functions as a Member; or $(e)$ has so abused his position, as to render his continuance in office prejudicial to the public interest; or $(f)$ is a practicing Member or an office bearer of any association representing surrogacy clinics, having financial or other interest likely to affect prejudicially, his function as a Member; or $(g)$ is an office bearer, heading or representing, any of the professional bodies having commercial interest in surrogacy or infertility.

Sub-clause (2) of this clause provides that the Members referred to in item $(f)$ of sub-clause (2) of clause 14 shall not be removed from his office except by an order of the Central Government on the ground of his proved misbehaviour or incapacity after the Central Government, has, on an inquiry, held in accordance with the procedure prescribed in this behalf by the Central Government, come to the conclusion that the Member ought on any such ground to be removed.

Sub-clause (3) of this clause provides that the Central Government may suspend any Member in respect of whom an inquiry under sub-clause (2) of clause 18 is being initiated or pending until the Central Government has passed an order on receipt of the report of the inquiry.

Clause 19.- This clause relates to temporary association of persons with Board for particular purposes.

Sub-clause (1) of this clause provides that the Board may associate with itself, in such manner and for such purposes as may be determined by the regulations, any person whose assistance or advice it may desire in carrying out any of the provisions of this Act.

Sub-clause (2) of this clause provides that a person associated with the Board under sub-clause (1) of clause 19 shall have a right to take part in the discussions relevant to that purpose, but shall not have a right to vote at a meeting of the Board and shall not be a Member for any other purpose. Board.

Clause 20.-This clause relates to authentication of orders and other instruments of

This clause provides that all orders and decisions of the Board shall be authenticated by the signature of the Chairperson and all other instruments issued by the Board shall be authenticated by the signature of the Member-Secretary of the Board.

Clause 21.-This clause relates to eligibility of Member for reappointment.

This clause provides that subject to the other terms and conditions of service as may be prescribed, any person ceasing to be a Member shall be eligible for reappointment as such Member. However, that no Member other than an ex officio Member shall be appointed for more than two consecutive terms.

Clause 22.- This clause relates to functions of Board.

This clause provides that the Board shall discharge the following functions, namely:(a) to advise the Central Government on policy matters relating to surrogacy; $(b)$ to review and monitor the implementation of the Act, rules and regulations made thereunder and recommend to the Central Government, changes therein; $(c)$ to lay down code of conduct to be observed by persons working at surrogacy clinics; to set the minimum standards of physical infrastructure, laboratory and diagnostic equipment and expert manpower to be 
employed by the surrogacy clinics; $(d)$ to oversee the performance of various bodies constituted under the Act and take appropriate steps to ensure their effective performance; (e) to supervise the functioning of State Surrogacy Boards; and $(f)$ such other functions as may be prescribed.

Clause 23.- This clause relates to Constitution of State Surrogacy Board.

Sub-clause (1) of this clause provides that the each State and Union territory having Legislature shall constitute a Board to be known as the State Surrogacy Board or the Union territory Surrogacy Board, as the case may be, which shall discharge the following functions, namely:- $(i)$ to review the activities of the appropriate authorities functioning in the State or Union territory and recommend appropriate action against them; (ii) to monitor the implementation of the provisions of the Act, rules and regulations made thereunder and make suitable recommendations relating thereto, to the Board; (iii) to send such consolidated reports as may be prescribed in respect of the various activities undertaken in the State under the Act to the Board and the Central Government; and (iv) such other functions as may be prescribed.

Clause 24.-This clause relates to composition of State Board.

This clause provides that the State Board shall consist of - (a) the Minister in-charge of Health and Family Welfare in the State, Chairperson, ex officio; (b) the Secretary in-charge of the Department of Health and Family Welfare, Vice-Chairperson, ex officio; (c) Secretaries or Commissioners in charge of the Departments of Women and Child Development, Social Welfare, Law and Justice and Home Affairs or their nominees, Members, ex officio; (d) Director General of Health and Family Welfare of the State Government, Member, ex officio; (e) three women Members of the State Legislative Assembly or Union territory Legislative Council, Members, ex officio; $(f)$ ten expert Members to be appointed by the State Government in such manner as may be prescribed, two each from amongst- $(i)$ eminent medical geneticists or human embryologists; (ii) eminent gynaecologists and obstetricians or experts of stri-roga or prasuti-tantra; (iii) eminent social scientists; (iv) representatives of women welfare organisations; and ( $v$ ) representatives from civil society working on womens' health and child issues, possessing of such qualifications and experiences as may be prescribed; $(g)$ an officer not below the rank of Joint Secretary to the State Government in charge of Family Welfare, who shall be the Member-Secretary, ex officio.

Clause 25.- This clause relates to term of office of Members.

Sub-clause (1) of this clause provides that the term of office of a Member, other than an ex officio Member, shall be- $(a)$ in case of nomination of three women Members of the State Legislative Assembly or Union territory Legislative Council, Members, ex officio, three years. However, that the term of such Member shall come to an end as soon as the Member becomes a Minister or Minister of State or Deputy Minister, or the Speaker or the Deputy Speaker of the Legislative Assembly, or the Deputy Chairman of the Legislative Council or ceases to be a Member of the House from which she was elected; $(b)$ in case of appointment of ten expert Members, one year. However, that the person to be appointed as Member under this clause shall be of such age, as may be prescribed.

Sub-clause (2) of this clause provides that any vacancy occurring in the office whether by reason of his death, resignation or inability to discharge his functions owing to illness or other incapacity, shall be filled within a period of one month from the date on which such vacancy occurs by the State Government by making a fresh appointment and the Member so appointed shall hold office for the remainder of the term of office of the person in whose place he is so appointed.

Sub-clause (3) of this clause provides that the Vice-Chairperson shall perform such functions as may be assigned to him by the Chairperson from time to time.

Clause 26.-This clause relates to meetings of State Board. 
Sub-clause (1) of this clause provides that the State Board shall meet at such places and times and shall observe such rules of procedure in regard to the transaction of business at its meetings (including the quorum at its meetings) as may be determined by the regulations. However, that the State Board shall meet at least once in four months.

Sub-clause (2) of this clause provides that the Chairperson shall preside at the meeting of the Board and if for any reason the Chairman is unable to attend the meeting of the State Board, the Vice-Chairperson shall preside at the meetings of the State Board.

Sub-clause (3) of this clause provides that the all questions which come up before any meeting of the State Board shall be decided by a majority of the votes of the Members present and voting, and in the event of an equality of votes, the Chairperson, or in his absence, the Vice-Chairperson shall have and exercise a second or casting vote.

Sub-clause (4) of this clause provides that the Members, other than ex officio Members, shall receive only compensatory travelling expenses for attending the meetings of the State Board.

Clause 27.-This clause relates to vacancies, etc., not to invalidate proceedings of State Board.

This clause provides that no act or proceeding of the State Board shall be invalid merely by reason of- $(a)$ any vacancy in, or any defect in the constitution of the State Board; or $(b)$ any defect in the appointment of a person acting as a Member of the State Board; or $(c)$ any irregularity in the procedure of the State Board not affecting the merits of the case.

Clause 28.- This clause relates to disqualifications for appointment as Member.

Sub-clause (1) of this clause provides that the a person shall be disqualified for being appointed and continued as a Member if, he- $(a)$ has been adjudged as an insolvent; or (b) has been convicted of an offence, which in the opinion of the State Government, involves moral turpitude; or (c) has become physically or mentally incapable of acting as a Member; or $(d)$ has acquired such financial or other interest, as is likely to affect prejudicially his functions as a Member; or $(e)$ has so abused his position, as to render his continuance in office prejudicial to the public interest; or $(f)$ is a practicing Member or an office bearer of any association representing surrogacy clinics, having financial or other interest likely to affect prejudicially, his function as a Member; or $(g)$ is an office bearer, heading or representing, any of the professional bodies having commercial interest in surrogacy or infertility.

Sub-clause (2) of this clause provides that the Members referred to in sub-clause $(f)$ of clause 24 shall not be removed from his office except by an order of the State Government on the ground of his proved misbehaviour or incapacity after the State Government, has, on an inquiry, held in accordance with the procedure prescribed in this behalf by the State Government, come to the conclusion that the Member ought on any such ground to be removed.

Sub-clause (3) of this clause provides that the State Government may suspend any Member in respect of whom an inquiry under sub-clause (2) of clause 28 is being initiated or pending until the State Government has passed an order on receipt of the report of the inquiry.

Clause 29.- This clause relates to temporary association of persons with State Board for particular purposes.

Sub-clause (1) of this clause provides that the State Board may associate with itself, in such manner and for such purposes as may be determined by the regulations, any person whose assistance or advice it may desire in carrying out any of the provisions of this Act.

Sub-clause (2) of this clause provides that a person associated with it by the State Board under sub-clause (1) of clause 29 shall have a right to take part in the discussions 
relevant to that purpose, but shall not have a right to vote at a meeting of the State Board and shall not be a Member for any other purpose.

Clause 30.-This clause relates to authentication of orders and other instruments of State Board.

This clause provides that all orders and decisions of the State Board shall be authenticated by the signature of the Chairperson and all other instruments issued by the State Board shall be authenticated by the signature of the Member-Secretary of the State Board.

Clause 31.- This clause relates to eligibility of Member for reappointment.

This clause provides that subject to the other terms and conditions of service as may be prescribed, any person ceasing to be a member shall be eligible for reappointment as such Member. However, that no Member other than an ex officio Member shall be appointed for more than two consecutive terms.

Clause 32.-This clause relates to appointment of appropriate authority.

Sub-clause (1) of this clause provides that the Central Government shall, within a period of ninety days from the date of commencement of this Act, by notification, appoint one or more appropriate authorities for each of the Union territories for the purposes of this Act.

Sub-clause (2) of this clause provides that the State Government shall, within a period of ninety days from the date of commencement of this Act, by notification, appoint one or more appropriate authorities for the whole or part of the State for the purposes of this Act.

Sub-clause (3) of this clause provides that the appropriate authority, under sub-clause (1) or sub-clause (2) of clause 32, shall,- $-(a)$ when appointed for the whole of the State or the Union territory, consist of - (i) an officer of or above the rank of the Joint Director of Health and Family Welfare Department-Chairperson; (ii) an eminent woman representing womens' organisation-Member; and (iii) an officer of Law Department of the State or the Union territory concerned not below the rank of a Deputy Secretary-Member; (iv) an eminent registered medical practitioner - Member. However, that any vacancy occurring therein shall be filled within one month of the occurrence of such vacancy; $(b)$ when appointed for any part of the State or the Union territory, be officers of such other rank as the State Government or the Central Government, as the case may be, may deem fit.

Clause 33.- This clause relates to functions of appropriate authority.

This clause provides that the appropriate authority shall discharge the following functions, namely:- $(a)$ to grant, suspend or cancel registration of a surrogacy clinic; $(b)$ to enforce the standards to be fulfilled by the surrogacy clinics; $(c)$ to investigate complaints of breach of the provisions of this Act, rules and regulations made thereunder and take legal action as per provision of this Act; $(d)$ to take appropriate legal action against the use of surrogacy by any person at any place other than prescribed, suo motu or brought to its notice, and also to initiate independent investigations in such matter; $(e)$ to supervise the implementation of the provisions of this Act, rules and regulations made thereunder; $(f)$ to recommend to the Board and State Boards about the modifications required in the rules and regulations in accordance with changes in technology or social conditions; $(g)$ to take action after investigation of complaints received by it against the surrogacy clinics; and $(h)$ to consider and grant or reject any application under the provisions of this Act.

Clause 34.-This clause relates to powers of appropriate authorities.

Sub-clause (1) of this clause provides that the appropriate authority shall exercise the powers in respect of the following matters, namely:- (a) summoning of any person who is in possession of any information relating to violation of the provisions of this Act, rules and regulations made thereunder; $(b)$ production of any document or material object relating to 
sub-clause $(a) ;(c)$ search any place suspected to be violating the provisions of this Act, rules and regulations made thereunder; and $(d)$ such other powers as may be prescribed.

Sub-clause (2) of this clause provides that the appropriate authority shall maintain the details of registration of surrogacy clinics, cancellation of registration, renewal of registration, grant of certificates to the intending couple and surrogate mothers or any other matter pertaining to grant of licence, etc., of the surrogacy clinics in such format as may be prescribed.

Clause 35.-This clause relates to prohibition of commercial surrogacy, exploitation of surrogate mothers and children born through surrogacy.

Sub-clause (1) of this clause provides that the no person, organisation, surrogacy clinic, laboratory or clinical establishment of any kind shall-(a) undertake commercial surrogacy, provide commercial surrogacy or its related component procedures or services in any form or run a racket or an organised group to empanel or select surrogate mothers or use individual brokers or intermediaries to arrange for surrogate mothers and for surrogacy procedures, at such clinics, laboratories or at any other place; $(b)$ issue, publish, distribute, communicate or cause to be issued, published, distributed or communicated any advertisement in any manner regarding commercial surrogacy by any means whatsoever, scientific or otherwise; (c) abandon or disown or exploit or cause to be abandoned, exploited or disowned in any form the child or children born through surrogacy; $(d)$ exploit or cause to be exploited the surrogate mother or the child born through surrogacy in any manner whatsoever; $(e)$ sell human embryo or gametes for the purpose of surrogacy and run an agency, a racket or an organisation for selling, purchasing or trading in human embryos or gametes for the purpose of surrogacy; $(f)$ import or shall help in getting imported in whatsoever manner, the human embryo or human gametes for surrogacy or for surrogacy procedures.

Sub-clause (2) of this clause provides that the notwithstanding anything contained in the Indian Penal Code, contraventions of the provisions of sub-clause (1) of clause 35 by any person shall be an offence punishable with imprisonment for a term which shall not be less than ten years and with fine which may extend to ten lakh rupees.

Sub-clause (3) of this clause provides that the for the purposes of this section, the expression "advertisement" includes any notice, circular, label, wrapper or any other document including advertisement through internet or any other media, in electronic or print form and also includes any visible representation made by means of any hoarding, wall-painting, signal light, sound, smoke or gas.

Clause 36.-This clause relates to punishment for contravention of provisions of Act.

Sub-clause (1) of this clause provides that the any registered medical practitioner, gynaecologists, pediatrician, human embryologists or any person who owns a surrogacy clinic or employed with such a clinic or centre or laboratory and renders his professional or technical services to or at such clinic or centre or laboratory, whether on an honorary basis or otherwise, and who contravenes any of the provisions of this Act (other than the provisions referred to in clause 35), rules and regulations made thereunder shall be punishable with imprisonment for a term which shall not be less than five years and with fine which may extend to ten lakh rupees.

Sub-clause (2) of this clause provides that the in case of subsequent or continuation of the offence referred to in sub-clause (1) of clause 36, the name of the registered medical practitioner shall be reported by the appropriate authority to the State Medical Council concerned for taking necessary action including suspension of registration for a period of five years.

Clause 37.- This clause relates to punishment for initiation of commercial surrogacy.

This clause provides that any intending couple or any person who seeks the aid of any surrogacy clinic, laboratory or of a registered medical practitioner, gynecologist, pediatrician, human embryologist or any other person for commercial surrogacy or for conducting 
surrogacy procedures for commercial purposes shall be punishable with imprisonment for a term which shall not be less than five years and with fine which may extend to five lakh rupees for the first offence and for any subsequent offence with imprisonment which may extend to ten years and with fine which may extend to ten lakh rupees.

Clause 38.- This clause relates to penalty for contravention of provisions of Act or rules for which no specific punishment is provided.

This clause provides that whoever contravenes any of the provisions of this Act, rules or regulations made thereunder for which no penalty has been elsewhere provided in this Act, shall be punishable with imprisonment for a term which shall not be less than three years and with fine which may extend to five lakh rupees and in the case of continuing contravention with an additional fine which may extend to ten thousand rupees for every day during which such contravention continues after conviction for the first such contravention.

Clause 39.- This clause relates to presumption in the case of surrogacy.

This clause provides that notwithstanding anything contained in the Indian Evidence Act, 1872, the court shall presume, unless the contrary is proved, that the women or surrogate mother was compelled by her husband, the intending couple or any other relative, as the case may be, to render surrogacy services, procedures or to donate gametes for the purpose other than those specified in sub-clause (ii) of clause 4 and such person shall be liable for abetment of such offence under clause 37 and shall be punishable for the offence specified under that clause.

Clause 40.- This clause relates to offence to be cognizable, non-bailable and noncompoundable.

This clause provides that notwithstanding anything contained in the Code of Criminal Procedure, 1973, every offence under this Act shall be cognizable, non-bailable and noncompoundable.

Clause 41.- This clause relates to cognizance of offences.

Sub-clause (1) of this clause provides that the no court shall take cognizance of any offence punishable under this Act except on a complaint in writing made by- $(a)$ the appropriate authority concerned, or any officer or an agency authorised in this behalf by the Central Government or the State Government, as the case may be, or the appropriate authority; or $(b)$ a person including a social organisation who has given notice of not less that fifteen days in the manner prescribed, to the appropriate authority, of the alleged offence and of his intention to make a complaint to the court.

Sub-clause (2) of this clause provides that the no court inferior to that of a Metropolitan Magistrate or a Judicial Magistrate of the first class shall try any offence punishable under this Act.

Clause 42.- This clause relates to certain provisions of the Code of Criminal Procedure, 1973 not to apply.

This clause provides that notwithstanding anything contained in the Code of Criminal Procedure, 1973, Chapter XXI A of the said Code relating to plea of bargaining shall not apply to the offences under this Act.

Clause 43.- This clause relates to maintenance of records.

Sub-clause (1) of this clause provides that the surrogacy clinic shall maintain all records, charts, forms, reports, consent letters, agreements and all the documents under this Act and they shall be preserved for a period of twenty-five years or such period as may be prescribed: However, that, if any criminal or other proceedings are instituted against any surrogacy clinic, the records and all other documents of such clinic shall be preserved till the final disposal of such proceedings. 
Sub-clause (2) of this clause provides that all such records shall, at all reasonable times, be made available for inspection to the appropriate authority or to any other person authorised by the appropriate authority in this behalf.

Clause 44.- This clause relates to power to search and seize records, etc.

Sub-clause (1) of this clause provides that if the appropriate authority has reason to believe that an offence under this Act has been or is being committed at any surrogacy clinic or any other place, such authority or any officer authorised in this behalf may, subject to such rules as may be prescribed, enter and search at all reasonable times with such assistance, if any, as such authority or officers considers necessary, such surrogacy clinic or any other place and examine any record, register, document, book, pamphlet, advertisement or any other material object found therein and seize and seal the same if such authority or officer has reason to believe that it may furnish evidence of the commission of an offence punishable under this Act.

Sub-clause (2) of this clause provides that the provisions of the Code of Criminal Procedure, 1973 relating to search and seizure shall apply, as far as may be, to all action taken by the appropriate authority or any officer authorised by it under this Act.

Clause 45.-This clause relates to protection of action taken in good faith.

Sub-clause (1) of this clause provides that no suit, prosecution or other legal proceeding shall lie against the Central Government or the State Government or the appropriate authority or any officer authorised by the Central Government or the State Government or by the appropriate authority for anything which is in good faith done or intended to be done in pursuance of the provision of this Act.

Clause 46.- This clause relates to application of other laws not barred.

This clause provides that the provisions of this Act shall be in addition to, and not in derogation of, the provisions of any other law for the time being in force.

Clause 47.-This clause relates to power to make rules.

This clause provides that the Central Government may, by notification and subject to the condition of pre-publication, make rules for carrying out the provisions of this Act.

Clause 48.- This clause relates to power to make regulations.

This clause provides that the Board may, with the prior approval of the Central Government, by notification, make regulations not inconsistent with the provisions of this Act and the rules made thereunder.

Clause 49.- This clause provides that every rule, regulation and notification made under the proposed legislation shall be laid, as soon as may be after it is made, before the House of Parliament.

Clause 50.- This clause relates to transitional provision.

This clause provides that subject to the provisions of this Act, there shall be provided a gestation period of ten months from the date of coming into force of this Act to existing surrogate mothers' to protect their well being.

Clause 51.-This clause relates to power to remove difficulties.

Sub-clause (1) of this clause provides that the if any difficulty arises in giving effect to the provisions of this Act, the Central Government may, by order published in the Official Gazette make such provisions not inconsistent with the provisions of the said Act as appear to it to be necessary or expedient for removing the difficulty. However, that no order shall be made under this section after the expiry of a period of two years from the date of commencement of this Act.

Sub-clause (2) of this clause provides that the every order made under this clause shall be laid, as soon as may be after it is made, before each House of Parliament. 


\section{FINANCIAL MEMORANDUM}

Clause (4) of section 16 and section 26 of the Surrogacy (Regulation) Bill, 2016 provides that for meetings of the National Surrogacy Board and State Surrogacy Board, the Members, other than ex officio Members, shall receive only compensatory travelling expenses for attending the meetings of such Boards. There will not be any financial implications except for the meetings of the National, State Surrogacy Boards and appropriate authorities which will be met out of the regular budget of the Central Government and State Governments.

2. The Bill does not involve any other expenditure of recurring or non-recurring nature from the Consolidated Fund of India. 


\section{MEMORANDUMREGARDINGDELEGATEDLEGISLATION}

Clause 47 of the Bill seeks to empower the Central Government, by notification and subject to the condition of pre-publication, to make rules for carrying out the provisions of this Act. In particular, and without prejudice to the generality of the foregoing power, such rules may provide for- $(a)$ the minimum qualifications for persons employed at a registered surrogacy clinic under clause (iii) of section 3; (b) the manner in which a person shall store human embryo or gamete under clause (vii) of section 3; (c) the insurance coverage in favour of the surrogate mother from an insurance company under item (III) of sub-clause $(a)$ of clause (iii) of section 4; (d) the number of attempts of surrogacy or providing of gametes under the proviso to item (III) of sub-clause (b) of clause (iii) of section 4; $(e)$ the form in which consent of a surrogate mother has to be obtained under clause $(i i)$ of section $6 ;(f)$ the number of oocytes or embryos to be implanted in the surrogate mother under section 8 ; $(g)$ the conditions under which the surrogate mother may be allowed for abortion during the process of surrogacy under section 9; $(h)$ the form and manner in which an application shall be made for registration and the fee payable thereof under sub-section (2) of section 10; (i) the facilities to be provided, equipment and other standards to be maintained by the surrogacy clinics under sub-section (4) of section 10; $(j)$ the, manner and form in which a certificate of registration shall be issued under sub-section $(1)$ of section $11 ;(k)$ the manner in which the certificate of registration shall be renewed and the fee payable for such renewal under sub-section (3) of section $11 ;(l)$ the manner in which an appeal may be preferred under section 13; $(m)$ the qualifications and experiences to the Members as admissible under clause $(f)$ of sub-section (2) of section 14; $(n)$ the procedures for conducting an inquiry against the Members under sub-section (2) of section 18; $(o$ ) the terms and conditions under which a Member of the Board eligible for re-appointment under section 21; $(p)$ the other functions of the Board under clause $(f)$ of section 22; $(q)$ the reports to be sent by the State and Union territory Boards to the Board and the Central Government under clause (iii) of section 23; $(r)$ the other functions of the State Board under clause (iv) of section 23; $(s)$ the qualifications and experiences to the members and the manner of their appointment under clause $(f)$ of section $24 ;(t)$ the age of the person to be appointed as a member, referred to in clause $(f)$ of section 24 , under the proviso to clause $(b)$ of sub-section (l) of section 25 ; (u) the procedures for conducting an inquiry against the members under sub-section (2) of section 28; $(v)$ the conditions under which the members of State Board eligible for reappointment under section $31 ;(w)$ appropriate legal action by appropriate authority under clause $(d)$ of section 33; $(x)$ the other powers of appropriate authority under clause $(d)$ of sub-section (1) of section 34; $(y)$ the particulars of the details of registration of surrogacy clinics, cancellation of registration etc. in such format under sub-section (2) of section 34; $(z)$ the manner of giving notice by a person under clause (b) of sub-section ( 1 ) of section 41; (za) the period up to which records, charts, etc., shall be preserved under sub-section (1) of section $43 ;(z b)$ the manner in which the seizure of documents, records, objects, etc., shall be made and the manner in which seizure list shall be prepared and delivered under sub-section (1) of section 44; and (zc) any other matter which is to be, or may be, or in respect of which provision is to be made by rules.

2. Clause 48 of the Bill empowers the Board, with the prior approval of the Central Government, by notification, to make regulations not inconsistent with the provisions of this Act and the rules made thereunder to provide for- $(a)$ the fulfilment of any other condition under which eligibility certificate to be issued by the appropriate authority under Item (IV) sub-clause (c) of clause (iii) of section 4; (b) the time and place of the meetings of the Board and the procedure to be followed for the transaction of business at such meetings and the number of Members which shall form the quorum under sub-section (1) of section 16; (c) the manner in which a person may be temporarily associated with the Board under sub-section (1) of section 19; (d) the time and place of the meetings of the State Board and the procedure 
to be followed for the transaction of business at such meetings and the number of members which shall form the quorum under sub-section $(I)$ of section 26; (e) the manner in which a person may be temporarily associated with the Board under sub-section (I) of section 29; and $(f)$ any other matter which is required to be, or may be, specified by regulations.

3. The matters in respect of which the said rules and regulations may be made are matters of procedure and administrative detail, and as such, it is not practicable to provide for them in the proposed Bill itself. The delegation of legislative power is, therefore, of a normal character. 


\section{LOK SABHA}

BILL

to constitute National Surrogacy Board, State Surrogacy Boards and appointment of appropriate authorities for regulation of the practice and process of surrogacy and for matters connected therewith or incidental thereto.

(Shri Jagat Prakash Nadda, Minister of Health and Family Welfare)

GMGIPMRND—3014LS(S3)-11-11-2016. 